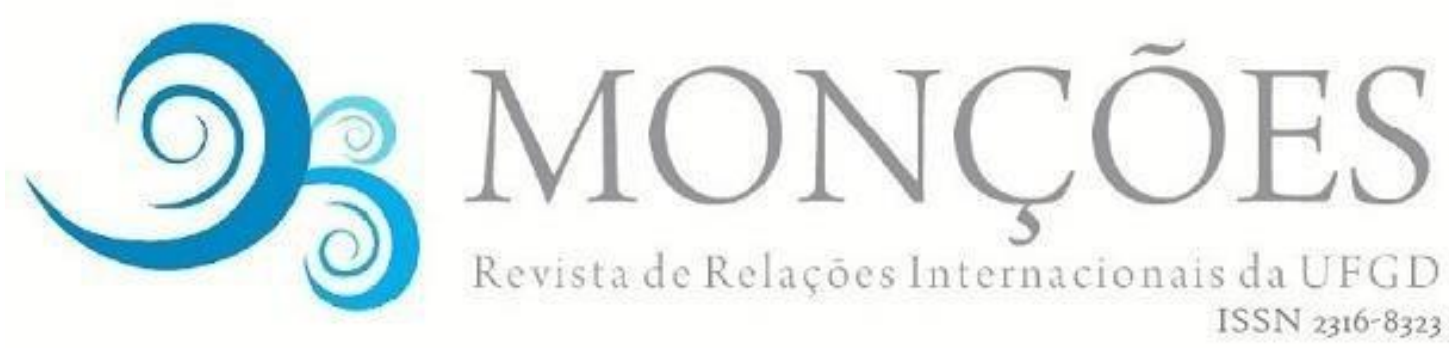

\title{
MULHERES GUERREIRAS: QUESTÕES DE GÊNERO NA PARTICIPAÇÃO FEMININA NAS FARC E SUA INFLUÊNCIA NAS NEGOCIAÇÕES DE PAZ NA COLÔMBIA
}

XAMAN MINILLO

Professora do Departamento de Relações Internacionais da Universidade Federal da Paraíba (UFPB), graduada (2008) e mestra (2011) em Relações Internacionais pela Universidade de Brasília

\section{BIANCA MENDES \\ Graduanda em Relações Internacionais pela UFPB}

LUIZA BANDEIRA

Graduanda em Relações Internacionais pela UFPB

\author{
REBECA LAGES \\ Graduanda em Relações Internacionais pela UFPB
}

\begin{abstract}
RESUMO: Este artigo busca analisar a participação das mulheres colombianas nas Forças Armadas Revolucionárias da Colômbia (FARC). A partir de um panorama histórico das origens e atividades do grupo guerrilheiro e da presença feminina nele, em conjunto com os motivos pelos quais mulheres se unem ao grupo, as funções e atividades que desempenharam dentro dele, são investigadas as oportunidades e desafios que as confrontam neste ambiente em termos de questões de gênero. Identifica-se que a atuação das mulheres nas FARC é ambígua do ponto de vista de gênero e simultaneamente apresenta possibilidades de transcendência de dicotomias tradicionais, mas também reafirma elementos de uma cultura masculinista marcada pelo militarismo e pela violência. Reconhecendo a importância da igualdade de gênero para a promoção da paz positiva, enfatiza-se a relevância do reconhecimento destas dinâmicas entre os guerrilheiros como um caminho necessário para a construção da paz na Colômbia.
\end{abstract}

PALAVRAS-CHAVE: FARC, Participação feminina, Acordo de Paz.

\section{WARRIOR WOMEN: GENDER ISSUES IN FEMALE PARTICIPATION IN FARC AND THEIR INFLUENCE IN THE COLOMBIAN PEACE AGREEMENT NEGOTIATIONS}

ABSTRACT: This article analyzes the participation of Colombian women in the Revolutionary Armed Forces of Colombia (FARC). Through a historical overview of the origins and activities of the guerrilla group and the female presence in it, as well as the reasons for which women join the group and the functions and activities they develop within it, the opportunities and challenges that confront them in this environment in terms of gender issues are investigated. It is identified that women's roles in the FARC are ambiguous from the point of view of gender and simultaneously presents possibilities of transcending traditional dichotomies, but also reaffirms elements of a masculinist culture marked by militarism and violence. Recognizing the importance of gender equality for the promotion of positive peace, the relevance of recognizing these dynamics among the guerillas as a necessary road for peacebuilding in Colombia is emphasized.

KEYWORDS: FARC, Female participation, Peace Agreement 


\section{I- INTRODUÇÃO}

Tradicionalmente, nos estudos de segurança, mulheres são tratadas em papéis secundários, como vítimas dos conflitos ou apoiadoras dos homens que assumem papel central nos embates políticos. É necessário questionar a falta de reconhecimento que as mulheres recorrentemente tiveram/têm em relação a seus papéis sociais, pois o fato da história registrada e da maioria dos trabalhos acadêmicos não considerarem a perspectiva de gênero como um fator relevante em questões de segurança denota uma prática que permeia a construção social da realidade, reafirmando a normalidade de se desconsiderar os papéis femininos na sociedade ou relegá-los ao segundo plano.

Inscrever as mulheres na história permite redefinir e alargar as noções tradicionais do que é historicamente relevante, podendo incluir tanto experiências pessoais e subjetivas, quanto atividades públicas e políticas (SCOTT, 1986). Para Scott, a maneira como esta nova história iria simultaneamente incluir e apresentar a experiência das mulheres dependeria da maneira como o gênero poderia ser desenvolvido enquanto categoria de análise. Assim, é imprescindível entender melhor os papéis das mulheres por questões não só acadêmicas, mas também políticas, em um mundo onde a violência é crescente (BLOOM, 2011 apud BRETTSCHNEIDER, 2014).

Em contextos de conflitos e violência, os corpos femininos são docilizados e as mulheres são simbolicamente ligadas à imagens de vitimização e necessidade de socorro (ELSHTAIN, 1987). Enquanto a violência masculina pode ser moralizada como uma atividade estruturada - de guerra - e por isso, despersonalizada e idealizada como parte das virtudes cívicas, as mulheres são excluídas do espaço público, sendo identificadas como "Belas Almas", atores cuja identidade é frágil e não-belicista (ELSHTAIN, 1987).

Seguindo esta tradição, boa parte da bibliografia, quando relaciona mulheres a conflitos armados, o faz enquadrando-as como civis, vítimas da 
guerra, ou apoiadoras de funções designadas para homens (GOLDSTEIN, 2001 apud GJELSVIK, 2010). No entanto, mulheres podem ter e têm papel relevante como agentes ativos, e não apenas vítimas, em cenários de conflito (WELSH, 2015), como pode ser visto no caso da participação feminina no grupo guerrilheiro das Forças Armadas Revolucionárias da Colômbia (FARC) ou em sua contribuição para a elaboração de um acordo de paz.

O envolvimento de mulheres como agentes em conflitos pode ser analisado a partir do exame do contexto econômico, social, político e ideológico que contribui para o alistamento feminino nos movimentos (STANSKI, 2006). Tratando-se de guerrilhas, é válido salientar que são caracterizadas por serem grupos sociais dotados de regras e sistemas hierárquicos distintos, porém relacionados à sociedade na qual estão inseridas (TORO, 1994 apud VEGA, 2016).

A participação de mulheres nas FARC, que cresceu desde os anos 1980, contribuiu para a quebra da ideia de que um cenário de conflito tradicionalmente não seja marcado pela presença feminina. $O$ reconhecimento da atuação das mulheres em diversas esferas, desde lavadeiras, cozinheiras, acompanhantes, espiãs ou na linha de frente, permite que as mulheres sejam vistas não apenas como vítimas, mas como agentes do movimento com papéis específicos na manutenção de uma cultura de violência. A inserção feminina nas FARC se apoiou em narrativas que promovem uma espécie de equidade de gênero através da identidade dos guerrilheiros (TURNER, 2016; SANCHEZ, 2012; STANSKI, 2005), aplicável a homens e mulheres e que desafia as fronteiras tradicionais entre os sexos.

$\mathrm{O}$ artigo oferece um panorama das questões de gênero que marcam a inserção feminina nas FARC. Trata das questões que impulsionam as mulheres a se envolverem no grupo, abarcando o histórico de violência que marca o país, as difíceis condições de vida e a expectativa de um ambiente mais igualitário onde possam lutar por uma sociedade melhor. Delineia a realidade que as mulheres enfrentam dentro do grupo a partir das áreas nas quais atuam e suas possibilidades de cresceimento dentro da hierarquia militar, assim como os 
desafios que as confrontam devido a seu gênero. Finalmente, levando em conta os problemas que a reafirmação de uma cultura de violência masculinizada e militar geram para a construção da paz, é levantada a participação feminina nas negociações de paz.

Estes aspectos serão analisados valendo-se da diferenciação entre "guerreiros justos" e "almas belas" proposta por Elshtain (1987) como elemento presente nos pensamentos e práticas associados às políticas de violência. Estes dois tipos ideais remetem aos papéis de gênero que associam o feminino à necessidade de proteção, compaixão e busca pela paz; e o masculino ao uso da violência militar legitimada pela prática de guerra em nome da proteção das belas almas. Desta relação, que caracteriza o mito da proteção, decorre o mito do poder que relaciona poder político como algo que é exercido apenas por aqueles que correspondam ao conceito de masculinidade, racionalidade, estratégia e força, que podem assumir o papel de protetores e desempenhar o poder político em nome de toda a sociedade (COSTA, 2008).

\section{II- UMA HISTÓRIA DE VIOLÊNCIAS}

A atuação das Forças Armadas Revolucionárias da Colômbia (FARC) pode ser entendida como fruto da cultura de violência presente no país desde 0 início de sua colonização e independência política. Segundo Costa (2008), o movimento nacionalista era promovido por uma elite local crioula que, inspirada nos princípios liberais europeus, sonhava em construir uma América emancipada em nome de um projeto civilizacional. Autora da história nacional e legitimada por sua cor e gênero que os aproximava dos civilizados europeus, a elite crioula promovia um discurso universalista em prol da emancipação americana que obscurecia as dimensões de gênero, raça e classe e se apoiava em critérios europeus para determinar as condições da civilização. Dessa forma, na independência, a dominação espanhola foi substituída pela dominação crioula descendente dos espanhóis (COSTA, 2008). 
Após a independência, o cenário político colombiano foi dominado pelas disputas entre conservadores e liberais, cada grupo com um projeto de desenvolvimento diferente para civilizar a nação. $O$ projeto conservador promovia a moral cristã e o liberal, por sua vez, uma ordem política embasada na lei secular. Os embates entre eles no contexto de um sistema agrário excludente resultaram em oito guerras civis que se estenderam até o final do século XIX (COSTA, 2008).

O sistema agrário colombiano, oligárquico e clientelista foi estruturado após a independência do território, sendo desenvolvido a partir da concentração de terras apoiada no sistema de leis de propriedade privada. As terras eram transferidas para particulares como retribuição a serviços prestados à nação pelos colaboradores dos partidos durante os conflitos em nome do progresso modernizador nacional que legitimava a exploração da mão de obra dos "selvagens" índios, negros e mestiços, em nome de civilizar o campo (COSTA, 2008). Costa (2008) aponta como, a partir da aliança entre as elites políticas do país, estruturaram-se duas Colômbias. Uma urbana, educada e sobo estado de direito e outra agrária, feudal, sob o controle de uma elite fundiária

e ocupada por uma massa de índios, negros e mestiços analfabetos, contra quem múltiplas violências são autorizadas em nome dos interesses econômicos, morais e políticos contingentes aos conflitos entre liberais e conservadores (COSTA, 2008, p.105-106).

$\mathrm{Na}$ primeira metade do século $\mathrm{XX}$,influenciados pelo pensamento marxista, sobretudo a partir da criação do Partido Comunista Colombiano, em 1930, os camponeses buscavam defender seus direitos contra a opressão dos donos das terras aliados dos líderes políticos por meio da luta armada, organizando-se em forças de autodefesa por todo o território colombiano (SANCHEZ, 2014).Costa (2008) salienta, no entanto, que assim como as elites políticas, os movimentos operário-camponeses também não se direcionaram às questões de raça ou gênero, reconhecendo estas desigualdades como subproduto do sistema capitalista, e propondo que combatendoeste, emergiria um movimento amplo de emancipação para todas as vítimas desta estrutura. 
Procurando conter as mobilizações agrário-camponesas e conciliá-las com o projeto liberal em oposição aos conservadores, o Presidente Alfonso López Pumarejo promoveu em seu governo o projeto "Revolução em Marcha", envolvendo reformas políticas, econômicas e sociais liberais em detrimento dos latifundiários. Intensificou-se, com isto, a violência no campo, que ganhou contornos de luta armada na década de 1940, confrontando milícias organizadas pelos fazendeiros com guerrilhas de camponeses estruturadas por liberais radicais que contavam com apoio do Partido Liberal (COSTA, 2008). Os confrontos desenrolaram-se na forma de guerrilhas vinculadas aos partidos tradicionais, sendo intensificados após o assassinato do líder político liberal Jorge Eliécer Gaitán em 9 de abril de 1948, que ocasionou uma onda de violência no país, o "Bogotazo"e iniciou o período denominado La Violencia, que gerou alto índice de deslocados e cerca de 200 mil mortos (PECAUT, 2008; DARIO, 2014; SANCHEZ, 2014).

Na segunda metade do século $X X$, a narrativa ocidental prevalente no âmbito internacional de guerra justa foi internalizada na Colômbia. Os dois partidos uniram-se em prol do governo da Frente Nacional, sob uma ditadura militar a partir do regime do General Rojas Pinilla que se estendeu até 1974, em nome da luta contra a tudo o que fosse entendido como ameaça comunista (COSTA, 2008; GUEVARA, 2010). Em nome dessa ameaça, o regime da Frente Nacional promoveu o treinamento de militares nos Estados Unidos e a Doutrina de Segurança Nacional a qual, a partir do Decreto 3398/1966 e da Lei 48/1968, autorizou a organização e o treinamento militar de grupos civis simpatizantes e colaboradores do regime de autodefesa no campo.

Procurando posicionar-se contra este regime, grupos e cooperativas de agricultores se mobilizaram desenvolvendo organizações de autodefesa chamadas de "Repúblicas Independentes" (GUEVARA, 2010). Em 1964, o governo iniciou a Operação Soberania, deslocando 16 mil soldados munidos de artilharia e poder aéreo para confrontá-las nas regiões de Marquetalia, Guayabero, Pato, Natagaima e Rio Chiquito (SANCHEZ, 2014). O ataque do exército colombiano a Marquetalia unificou uma série de grupos de autodefesas transformando-os em guerrilhas móveis. Em 1964, formou-se o grupo Bloco Sul 
e, após um processo de expansão territorial e a Segunda Conferência Guerrilheira, em 1966, foram constituídas as "Forças Armadas Revolucionárias da Colômbia" (FARC), com aproximadamente 350 guerrilheiros (PEREIRA, 2015; PECAUT, 2008; SANCHEZ, 2014).

Destaca-se que as FARC emergiram a partir de inúmeros aspectos políticos e sociais, além de simbólicos em um contexto de desigualdade e concentração fundiária oligárquica e repressão do Estado aos camponeses. É notável que:

\begin{abstract}
Elas faziam parte da tradição das "guerras civis" colombianas e da contestação violenta da legitimidade do poder, portanto suas raízes estavam vinculadas a um longo período da história da Colômbia; situavam-se na continuidade dos conflitos agrários, portanto, num período mais recente da história; remetiam à experiência recente de La Violencia, isto é, a uma memória imediata e, por fim, inseriam-se na experiência contemporânea do radicalismo revolucionário antiimperialista. Logo, eram ao mesmo tempo "tradicionais" e "modernas". Estavam impregnadas da sociedade rural e de reivindicações campesinas e, ao mesmo tempo contidas na efervescência das concepções emancipadoras, mas também estavam subordinadas a um partido comunista vinculado à visão "clássica" da revolução, em que o proletariado desempenha o papel principal (PECAUT, 2008, p.19)
\end{abstract}

A partir desta breve exposição a respeito do histórico das FARC, pode-se apreender o contexto de violência estrutural que marca a sociedade colombiana. Levando em conta este contexto, a próxima seção do artigo trata a inserção feminina no movimento, abarcando tanto os fatores que contribuíram para sua entrada, quanto as dinâmicas que as envolveram no interior do grupo guerrilheiro.

\title{
III- A INSERÇÃO FEMININA NAS FARC
}

Antes de desenvolver o panorama de elementos que direcionam a participação feminina nas FARC, é válido relembrar que a atuação de mulheres em áreas de segurança ainda não é amplamente reconhecida. Deve-se evitar, 
ao analisar as motivações das mulheres ao participarem de grupos revolucionários e radicais, a preconcepção de que elas o fariam apenas por serem obrigadas ou coagidas por homens para tal, como se não pudessem ter um desejo próprio (TURNER, 2016). É reconhecido, assim, o papel da participação ativa e calculada das mulheres nessa decisão em busca de uma forma de controlarem suas vidas (STANSKI, 2006; WELSH, 2015), sem desconsiderar que tais escolhas se desenvolvem em contextos específicos, sendo que as duras condições da sociedade colombiana muitas vezes oferecem opções escassas e pouco ou nenhum espaço para que as escolhas sejam tomadas de forma livre.

A Colômbia apresenta um contexto sócio-econômico conturbado, marcado pela violência e pela pobreza (CERAC, 2014). Com uma das maiores taxas de homicídio das Américas (ONU BRASIL, 2017), é considerada o décimo Estado mais violento do mundo; seus conflitos envolvendo disputas por terras, tráfico de drogas, disponibilidade de armas e machismo (PACHÓN, 2009 apud MARTUSCELLI, 2015). Cerca de $30 \%$ da população vive abaixo da linha da pobreza, sendo mais de $45 \%$ da renda nacional concentrada pelos $10 \%$ mais ricos (BJØRKHAUG, 2010 apud MARTUSCELLI, 2015).

O país ocupa a posição 91 entre 186 Estados quanto à igualdade de gênero e embora tenham direito a participação política e a métodos contraceptivos e o acesso à educação tenha melhorado ao longo dos anos, a realidade das colombianas é marcada por violências fruto dos conflitos, de cunho sexual, reprodutivo, doméstico e psicológico, e muitas encontram apenas no casamento e na maternidade ${ }^{1}$ valorização social (SANCHEZ, 2012; CALEIROS, 2014; SAYAGO, 2016).

\footnotetext{
${ }^{1}$ Houve certo avanço em termos de direitos sexuais e reprodutivos das mulheres na Colômbia, em 2006, quando o aborto passou a ser permitido por lei se a gravidez fosse resultado de estupro ou incesto; se colocasse em risco a saúde mental ou física da mulher; ou caso os fetos apresentam malformações e não pudessem viver fora do útero (EL TIEMPO, 2016). Entretanto, apenas 0,08\% das 400.000 mulheres que abortam a cada ano na Colômbia buscam a rede hospitalar (PALOMINO, 2016). Houve um aumento no uso de métodos contraceptivos (BANCO MUNDIAL, 2017c) passando de 42,5\% em 1980 para 79,1\% em 2010, o que indica uma melhora nas possibilidades de escolha quanto à reprodução e influenciou na redução da taxa de fertilidade de 6,807 em 1960, a 3,965 em 1980, 2,389 em 2000 e 1,875 em 2015.
} 
Uma combinação multifacetada de questões históricas e culturais sustenta a ideia de que as mulheres não têm o mesmo valor dos homens na construção do Estado colombiano. O desenvolvimento deste deu-se sob o controle da elite de homens crioulos e de acordo com seu projeto civilizacional de promover "instituições capazes de minimizar as limitações "naturais" de mulheres, índios, negros, mulatos e mestiços, trazendo-Ihes alguma iluminação" (COSTA, 2008, p.76). Neste projeto, o feminino tem espaço complementando e auxiliando o papel masculino nos conflitos que marcam a sociedade (ELSHTAIN, 1987, p.164 apud COSTA, 2008, p.81)

As mulheres, principalmente aquelas pobres e que vivem em meio rural, não possuem as mesmas oportunidades oferecidas aos homens, devido à pouca penetração do Estado no fornecimento de bens públicos e deixando as populações expostas à atuação de movimentos armados (SAYAGO, 2016; MARTUSCELLI, 2015). Essa assimetria é notável no âmbito econômico. Muitas mulheres, especialmente da zona rural, não têm renda própria, o que indica uma falta de autonomia econômica (CEPAL, s.d.). Salienta-se que a ausência de renda própria não significa ausência de trabalho e pode-se entender que as mulheres realizam trabalho doméstico não computado como atividade produtiva ou atividades informais. Os trabalhos das camponesas tratam-se, majoritariamente, daqueles sazonais e intensivos em mão de obra, como em colheitas de algodão e café; elas trabalham em jornadas mais longas e recebem menos que os homens por suas atividades, além de acumularem jornadas duplas como donas de casa (MEERTENS, 2000 apud COSTA, 2008).

Tem havido lenta melhora no sistema educacional do país nas últimas décadas (UNESCO, 2016), mas as mulheres colombianas enfrentam dificuldades na obtenção de educação, o que impacta sua inserção no mercado de trabalho, tornando-as mais suscetíveis ao desemprego (GJELSVIK, 2010; ZWEHL, 2014). No ano de 2013, a diferença de participação laboral foi de 20,94\% (em comparação com 26,63\% em 2001)e em 2012, disparidades salariais de gênero foram de 23,28\% (em comparação com 17,61\% em 2002). Segundo Costa (2008), a inclusão feminina no mercado de trabalho no início do 
século XX desenvolveu-se atribuindo menor custo ao trabalho feminino, visto como "naturalmente" menos eficiente que o masculino.

Nesse cenário de pouca oportunidade, as FARC se apresentaram como uma chance de escape de uma realidade de dependência e pobreza principalmente para as meninas e mulheres que viviam no meio rural sem prospecções futuras. Mais de 11 mil crianças e jovens entraram para a guerrilha de 1975 a 2013, das quais cerca de 28\% eram meninas² (SAYAGO, 2016; VEGA, 2016; ESTADÃO, 2016; FOLHA DE S. PAULO, 2016; O DIA, 2016; WELSH, 2015).

A Human Rights Watch (apud STANSKI, 2006) aponta que a decisão de se juntar a forças militares irregulares refletiu as oportunidades sombrias disponíveis para as crianças na Colômbia rural, sendo a situação sócioeconômica das mulheres fator essencial para entender sua entrada no movimento para lutar por uma sociedade mais justa ${ }^{3}$ (STANSKI, 2006). Isto fica claro no depoimento de Olga Lucía Marín, comandante das FARC: "Eu também gostada da ideia de que lutávamos para criar uma sociedade diferente, mais justa, sem fome" (Lara, 2000, p.90 apud COSTA 2008, p.114; tradução livre). 0 grupo guerrilheiro descrevia sua política como um meio onde mulheres podiam lutar, ter tratamento igualitário, proteção e direitos; e convidava-as a participarem da luta revolucionária por uma Nova Colômbia mais justa, digna e com melhor qualidade de vida.

Nas FARC - Exército do Povo, nós mulheres nos sentimos realizadas em nossa condição de lutadoras revolucionárias. Temos alcançado espaço entre os milhares de combatentes. Operárias, camponesas, estudantes, profissionais e intelectuais, das diferentes raças

\footnotetext{
${ }^{2}$ Salienta-se que, desde 2016, a partir de acordo com o governo colombiano, as FARC iniciaram o processo de devolução à sociedade crianças anteriormente recrutadas. Os menores são recebidos pelo Comitê Internacional da Cruz Vermelha, onde fazem exames médicos e psicológicos, além de participar de um programa de reabilitação para que possam ser reintegrados na sociedade (ESTADÃO, 2016; FOLHA DE S. PAULO, 2016; O DIA, 2016).

${ }^{3}$ A Colômbia ainda é um dos países latino-americanos com a menor representação feminina na política. Em 2015 elas são apenas 14\% do Conselho, de 17\% dos MPs, 10\% dos prefeitos e $9 \%$ dos governadores, números ainda bem abaixo da paridade que faria justiça para com a proporção de mulheres na sociedade.
} 
colombianas, aqui têm seu lugar. (...)Nesses quarenta anos de luta das FARC-Exército do Povo, nós mulheres alcançamos progressos fundamentais quanto à participação e igualdade. Homens e mulheres nos comprometemos com as determinações dos organismos de direção e cada qual contribui com o que sabe, pode e deve fazer. Ombro a ombro com nossos camaradas, seguimos na luta pela segunda e definitiva independência e pelos direitos específicos das mulheres. Conscientes de que isso só é possível agora nas FARC-EP e na nova sociedade que construiremos com o triunfo da revolução. (Marín, 2003 apud COSTA, 2008, p.117-118).

Segundo Costa (2008), até os anos de 1980, quando as FARC passaram a estimular a entrada das mulheres, estas participavam exercendo papéis auxiliares aos guerreiros, homens, estruturando redes de apoio aos grupos armados oferecendo-Ihes comida, limpeza, costura, além de informações. A partir de então, o grupo passou a reconhecer o interesse das mulheres em lutar contra o Estado capitalista patriarcal, convocando-as a apoiarem seu projeto emancipatório inclusive na luta armada. Segundo Costa (2008), "a guerrilha incorpora em seu discurso a necessidade de transformar o papel tradicional das mulheres, construindo um espaço político de maior igualdade entre homens e mulheres" (LONDONÕ; NIETO, 2006, p.51 apud COSTA, 2008, p.117).

Tal abertura mostrou-se para muitas uma nova forma de agência e inclusão política. A inclusão das mulheres como guerrilheiras nas FARC desafiou os papéis tradicionais de gênero e a igualdade dentro da hierarquia militar emergiu como um caminho para a emancipação e para o desafio às regras de socialização feminina. Este ponto, que será desenvolvido em mais detalhe na próxima seção, remete ao questionamento pelas FARC da dicotomia entre as belas almas e os guerreiros justos tradicionalmente atrelados às diferenças de gênero, e é ilustrado aqui no depoimento de uma ex-combatente:

Mulheres e homens fazem o mesmo. Comunismo e igualdade. Um homem é posto de plantão no serviço de segurança, mulheres fazem o mesmo, [você] carrega a mesma quantidade de quilos. Só porque você é mulher não significa que você deve carregar uma quantidade menor que homens, caminhar menos que homens (Leidy, exguerrilheira, apud GJELSVIK, 2010, p.42; tradução livre). 
Salienta-se que essa igualdade não questionava os modelos de masculinidade constituintes da cultura da violência colombiana. $O$ destaque para a masculinidade militar, corporificada no treinamento das guerrilhas como elemento chave em sua simbologia, sendo o soldado o símbolo da cidadania exemplar (ELSHTAIN, 1987 apud MONTE, 2010), estende a masculinidade militarizada às mulheres, fazendo com que a violência seja vista como necessária para a transformação dos papéis de gênero (MEERTENS, 1995, p.49 apud COSTA, 2008).

Esta reafirmação da violência como parte da prática social é ambígua levando em conta que, dentre as múltiplas violências que são perpetradas contra as mulheres, muitas se devem ao conflito, envolvendo ameaças, assassinato, terrorismo, tortura, desaparecimento involuntário, escravidão sexual, estupro, abuso sexual, gravidez forçada e abortos. Os dados oficiais indicam que mais de 400.000 mulheres foram mortas devido ao conflito armado, e entre 1995 e 2011, mais de 2.700.000 mulheres tiveram de se deslocar internamente (cerca de 6\% da população total colombiana e $51 \%$ de todos os deslocados), $15,8 \%$ das quais relatam ter sido vítimas de violência sexual. Mulheres pertencentes a grupos étnicos indígenas e afro-colombianos foram desproporcionalmente afetadas pela violência: de 3.445 casos de assassinatos de indígenas e afro-colombianos, 65,5\% eram mulheres(ONU MUJERES, 2017).

Ainda assim, a busca por segurança era um dos motivos pelos quais as mulheres se juntavam às FARC. Mulheres que sofriam constante violência doméstica buscaram a guerrilha como forma de escapar da hostilidade e abusos que sofriam no lar ${ }^{4}$. Mesmo com uma melhoria na consciência da população nos últimos anos acerca do assunto, os progressos ainda eram mínimos e a impunidade (dos homens) e o silêncio (das mulheres) permaneciam (WELSH,

\footnotetext{
${ }^{4} U \mathrm{~m}$ a cada três casos de violência doméstica contra mulheres envolvem casais e $23 \%$ envolvem membros da família (OCDE, 2009 apud GJELSVIK, 2010). Em relação aos números da violência contra as mulheres, o relatório do Instituto Nacional de Medicina Legal da Colômbia (INMLCF) mostra que, em 2014, foram assassinadas 1.007 mulheres, 37.881 casos de violência foram relatados contra as mulheres no âmbito de relacionamentos amorosos e 16.088 casos de violência sexual, sendo elas $86 \%$ do total das vítimas deste crime, além de meninas e adolescentes serem as principais afetadas por esta forma de violência.
} 
2015; ZWEHL, 2014). Compreende-se o incentivo para entrar nas FARC por parte de, por exemplo, vítimas de violência doméstica, pois

\begin{abstract}
Nas FARC, eles não podem tocar em você. Por lei. Os homens não podem bater em você e não só porque é requerido que eles não te toquem, mas porque nós mulheres também carregamos armas, então quando você está lá, os homens te respeitam porque você tem uma arma. Se você me tocar, eu posso atirar em você. É por isso que há menos violência contra as mulheres nas FARC que na vida civil. Você não tem que esperar por alguém para te defender. Você o faz sozinha. Agora, quando um cara bate em você, você sabe que tem de fazê-lo respeitá-la e eu aprendi isso nas FARC. Na vida civil há mais violência e mais impunidade e aqueles que cometem crimes não são punidos. Nas FARC, eles são. Se você der mole, você paga por isso (Natalia, combatente entrevistada por MENDEZ em Bogotá, 2010 apud MENDEZ, 2012, p.133-134; tradução livre).
\end{abstract}

No contexto de opressão, pobreza e marginalização, o desejo de contribuir para a estruturação de uma sociedade mais justa, unido à possibilidade de serem tratadas como iguais aos homens, oferecida às mulheres no discurso oficial das FARC seduziram muitas mulheres e meninas a se juntarem ao grupo (WELSH, 2015; STANSKI, 2006; TURNER, 2016). Entretanto, a realidade que confronta tais expectativas precisa ser examinada detalhadamente. Para tal, a próxima seção tratará do ambiente que as mulheres encontraram na hierarquia militar das FARC e suas possibilidades de atuação.

\title{
IV- A ATUAÇÃO FEMININA NAS FARC
}

\section{a. A igualdade opressora da hierarquia militar masculinista}

Dentro das FARC, as mulheres recebiam, assim como os homens, educação, que é bastante valorizada pelo grupo. Em grande medida sob a atuação do intelectual Jacobo Arenas, a guerrilha ensinava filosofia, economia e sociologia a seus membros. Sob o preceito da igualdade de todos, eram 
incluídas mulheres, camponeses, negros, indígenas e mestiços, educados e treinados para serem iguais sob a hierarquia do grupo (COSTA, 2008).

Dentro desta hierarquia todos deviam atuar em prol do benefício da organização e, de acordo com suas capacidades - determinadas pela capacidade física e pelo conhecimento - podiam ser promovidos na estrutura pré-determinada do movimento (TURNER, 2016; COSTA, 2008).No treinamento, quando inseridas nas guerrilhas, mulheres recebiam os mesmos ensinamentos que os homens. Isto envolvia o manejo de armas e comportamento em combate, além do preparo físico dos combatentes sem distinção de gênero quanto ao tipo de fardamento e o acesso a armas, contribuindo para o discurso de igualdade entre homens e mulheres dentro do movimento, como pode ser notado no depoimento de Olga Lucía Maria, guerrilheira das FARC (STANSKI, 2006; TURNER, 2016).

O que se tinha claro era que a guerrilha foi uma luta importante. Mas não se pensava na questão militar. Minha tarefa era colaborar com o ensino. Eu não me encantava pelas armas. (...) Na Frente Dezesseis havia poucas armas. Quando eu fui fazer guarda, me deram um revólver pequeno de 32. As pessoas diziam que ele era inútil. Mas era a minha arma. E eu aprendi a desejá-la, a desmontá-la, a limpá-la, a cuidar da munição, a fabricar a peça onde ela era guardada (LARA, 2000, p.94-104 apud COSTA, 2008, p.118-119, tradução livre).

Entretanto, os treinamentos mais avançados eram dados de acordo com a capacidade dos combatentes e recaía, sobre as mulheres, o peso da expectativa de certa inaptidão física assumida como natural. Para avançarem no grupo, elas precisavam rejeitar os padrões dominantes de feminilidade, correspondendo a um modelo determinado a partir de características masculinas - o ideal do guerreiro justo -, reproduzindo uma lógica militar de identidade política e reforçando uma concepção de poder embasada na masculinidade militarizada (COSTA, 2008). Isto fica claro no depoimento de Carmem Lucía (nome fictício), ex-guerrilheira integrada ao Programa Paz y Reconciliação:

Quando chegamos ao acampamento, ficamos deslumbradas com tanta coisa nova que nos ensinam. Ficamos impressionadas que 
podemos aprender a usar uma arma. Mas depois quando se vê para que serve essa arma, elas não parecem tão boas assim. Mas lá temos armas porque é necessário e não por amor a elas. Lá nos ensinavam que o que há é para todos (Carmen Lucía, entrevista para Costa feita em Medellín, 2007 apud COSTA, 2008, p.199).

Sob o ideal de contribuir para uma "Nova Colômbia", as mulheres tinham espaço para redefinir seu papel social desafiando fronteiras tradicionais de gênero, o que podia trazer, como indica o relato abaixo, muito orgulho:

\begin{abstract}
Eu fui soldado. Minha qualidade de mulher por definição biológica não me atrapalhou, mas eu também não estava muito consciente do que isso significava em um mundo que nos homologava em torno de ideologias. Pesava mais a igualdade que a diferença. Desde muito pequena, apoiada por minha mãe, rejeitei os valores tradicionalmente atribuídos às condições femininas: a delicadeza, ou melhor, o melindre, a dedicação ao lar, a habilidade culinária, o sonho de casamento precoce, a maternidade e a virgindade (...). O mundo dos homens não era desconhecido, e isso facilitou a minha entrada para o âmbito político-militar de um grupo guerrilheiro, cujas práticas, tanto políticas como militares, estavam claramente inscritas em um universo masculino, eram coisas de homens (VASQUEZ, 2006, p.354-355 apud COSTA, 2008, p.199, tradução nossa).
\end{abstract}

Percebe-se como esta cultura característica do ambiente das FARC desafiou as diferenciações de gênero do mito da proteção exercida pelos guerreiros justos para as belas almas. As mulheres, tradicionalmente vistas como belas almas, ao tornarem-se guerrilheiras e atuarem em atividades de combate, passam a ser responsáveis pela segurança do grupo, pela busca da "Nova Colômbia": tornaram-se guerreiros justos. Esta valorização de características frequentemente associadas ao masculino atuava em detrimento de algumas mulheres no movimento, cujo perfil podia impedir que se integrassem nas atividades de linha de frente desfavorecendo-as na hierarquia militarizada. Ao mesmo tempo em que se subvertiam os papéis de gênero tradicionais do mito da proteção, se reafirmava o mito do poder masculino, pois para ascender na hierarquia das FARC era preciso corresponder ao conceito de masculinidade militar estratégica e racional (COSTA, 2008). 
A hierarquia das FARC era norteada por sistemas de regras e sanções, fundamentada na dura disciplina aplicada a todos os membros igualmente (STANSKI, 2006; VEGA, 2016), "lá, seja você velha ou jovem, é da mesma forma, não há diferenças em nada" (Paola, ex-combatente das FARC, apud NINO VEGA, 2016, p.36). "Um menino tem que fazer o mesmo que faz um maior, é igual; lá não há privilégio para ninguém; se o fuzil lhe fica grande, ele tem que dar um jeito; se o uniforme lhe fica grande, ele que o arrume. Todos são iguais, não há diferença" (María, ex-combatente do ELN e das FARC apud NINO VEGA, 2016, p.36).

Todos estavam sujeitos às regras dos superiores e, se não cumprissem a disciplina, podiam sofrer penalidade severas. Dentro desta hierarquia, as mulheres podiam ser mais ou menos respeitadas de acordo com seus cargos (STANSKI, 2006). A expectativa de igualdade sob o controle da hierarquia atraía muitas mulheres ao movimento, como foi explanado na seção anterior. Entretanto, as expectativas de tratamento igualitário de algumas combatentes foram frustradas pela naturalização da inferioridade das mulheres dentro do movimento, como pode ser notado no relato de Olga Lucía Marín (COSTA, 2008), comandante das FARC:

\begin{abstract}
É frequente que as guerrilheiras sintam que não podem discordar do companheiro para não pegar mal. Na Guerrilha, como na Colômbia, há machismo. Os guerrilheiros também se formaram dentro de uma sociedade machista. O machismo existe nas FARC. Entretanto, na Oitava Conferência foi estabelecido que a mulher na guerrilha é livre e não pode ser discriminada. Ela tem os mesmos direitos e deveres que homens. Ou seja, se uma mulher quer impedir que a discriminem, são disponíveis os instrumentos para que ela consiga. (...) É necessário que as mulheres saibam lutar, e se o fizerem bem, ganham. $\mathrm{Na}$ guerrilha há cerca de $40 \%$ das mulheres. A mulher tem uma boa participação, como ocorre na Colômbia. Porém no país ainda se enxerga a mulher com desprezo, como algo secundário. É importante assegurar que tanto na guerrilha, como no país, se eleve o papel da mulher, que a aprecie mais (LARA, 2000, p.114-115 apud COSTA, 2008, p.120; tradução livre).
\end{abstract}

Desta forma, percebe-se que, apesar de formalmente terem os mesmos direitos e receberem os mesmos ensinamentos básicos, homens e mulheres não possuíam as mesmas oportunidades dentro da hierarquia militarizada das FARC 
e muitas não ousavam demandar seus direitos. Ademais, ainda que algumas chegassem a posições de liderança dentro do grupo, homens tinham maiores chances devido ao ideal de guerrilheiro ser embasado em imagens de masculinidade militar (TURNER, 2016; STANSKI, 2006).

\section{b. Atuação em atividades de apoio}

Além das atividades de "linha de frente", manuseando armas, explosivos e patrulhando, as mulheres atuavam mais frequentemente em áreas de apoio, recrutando membros, desenvolvendo coletas de informação, operando equipamentos de rádio e realizando atividades de logística e de finanças, além de serviços médicos e de enfermaria (SANCHEZ, 2012; TURNER, 2016) ${ }^{5}$. Essa atuação, ainda que estrategicamente de grande relevância para o grupo, reafirmava estereótipos de gênero situando as mulheres em posições de apoio; as belas almas em posições secundárias com relação aos guerreiros justos (COUNCIL ON HEMISPHERIC AFFAIRS, 2010; SANCHEZ, 2012; TURNER, 2016).

O serviço de inteligência era uma forma importante de atuação feminina nas FARC, acreditando-se que estas tinham maior facilidade e efetividade no desenvolvimento deste papel. Isto se deve às pré-concepções de gênero presentes na sociedade colombiana, que não percebem as mulheres como perigo, associando-as simbolicamente a "belas almas". Tal pressuposto permitia às mulheres mais facilidade em se disfarçar no desempenho de atividades de inteligência, espionagem e transporte de mensagens (SANCHEZ, 2012). Notase, assim, como o próprio sexismo da sociedade era reafirmado e instrumentalizado dentro do grupo.

${ }^{5}$ Foi a partir da década de 1980 que as FARC passaram a estimular a inserção das mulheres em seu meio. Antes disso, elas já atuavam em redes de apoio fundamentais para a atuação dos grupos armados em atividades de cuidado, como acompanhantes dos homens, lavadeiras, cozinheiras e costureiras, além de informantes e na vigilância. A partir de então, quando 0 Secretariado decretou que pessoas de qualquer raça, etnia ou gênero poderiam entrar na guerrilha sem discriminação (WELSH, 2015), suas atividades tornaram-se mais diversificadas e elas passaram a ser reconhecidas como iguais, desempenhando atividades de combate antes restritas (SAYAGO, 2016; COSTA, 2008). 
Para tal, muitas vezes elas atuavam disfarçadas de empregadas ou prostitutas (COUNCIL ON HEMISPHERIC AFFAIRS, 2010; TURNER, 2016), ecoando a história da mártir da independência nacional, Policarpa Salavarrieta, "La Pola". Membro do movimento contra a tentativa de reconquista de Bogotá pela Espanha no final do século XIX, ela atuou como espiã trabalhando como empregada doméstica em casas de monarquistas e conseguiu informações importantes para o movimento de independência contando com os estereótipos associados a mulheres - ingenuidade, fragilidade e alienação política (COSTA, 2008: 82).

Este tipo de atuação denota, mais uma vez, que apesar do ideal de igualdade entre homens e mulheres, as ações dentro da guerrilha tenderam a naturalizar e reproduzir as desigualdades de gênero, direcionando as mulheres a atividades específicas a partir do pressuposto de que elas são fisicamente inferiores, inaptas para atuar de acordo com os ideais de masculinidade militarista. A própria condição de serem mulheres era percebida, ainda que não oficialmente, como uma fraqueza que as impedia de desempenhar determinados cargos, devendo assim, dedicarem-se principalmente a atividades de apoio.

Um dos fundamentos para a reconstrução de minha identidade era o reconhecimento de minhas diferenças de gênero, as quais davam conta de boa parte de meus comportamentos, tanto nas estruturas militares como nas relações afetivas. Não foi fácil naquele tempo identificar a inequidade e a discriminação, nem muito menos o poder exercido sobre nós mulheres pelos homens. $E$ isso que o Eme, talvez devido à sua composição social - estudantes, classe média urbana, intelectuais - foi dentre os grupos guerrilheiros uma das organizações mais abertas à população feminina em alguns cargos de direção. $O$ que não significa que não existiu o machismo, acredito que essa é uma condição inerente aos exércitos. Acontecia que, tanto para nós mulheres, como para os homens, muitas situações de inequidade estavam naturalizadas pela cultura, não eram visíveis, e por isso não as sentíamos nem as reivindicávamos (...). Acredito que igual ocorreu com muitas: embora tivéssemos a coragem de assumir a quebra das instituições vigentes, nós estamos presas pelas formas de agir próprias das mulheres na sociedade de nosso tempo. Cedemos espaços de autonomia um após o outro, assumimos que os afazeres domésticos e o cuidado dos filhos eram de responsabilidade fundamental das mulheres, aceitamos que as atividades dos companheiros tenham maior importância que as nossas, sacrificamos nosso crescimento por apoiá-los; no fim, renunciamos nossos próprios projetos, o que desejávamos e o que esperávamos da vida em função, primeiro, da organização e, em seguida, dos nossos amados companheiros 
(...). No entanto, nossa prática trouxe novos elementos à forma de ser mulher (...) o que evidenciou contradições entre o tradicional e o que foram as guerreiras como parte de um projeto político (VÁSQUEZ, 2006, p.356-357 apud COSTA, 2008, p.200, tradução livre).

O exame dos papéis desempenhados majoritariamente pelas mulheres dentro da estrutura das FARC demonstrou que, sob o discurso de deveres e responsabilidades iguais entre homens e mulheres, mesmo uniforme e a possibilidade de todos pegarem em armas, mulheres nas FARC enfrentavam barreiras para atuar em algumas áreas simplesmente por serem mulheres (WELSH, 2015).

\section{c. $\quad$ controle sexual e reprodutivo}

A questão sexual é significativa, pois é local de frequentes embates relacionados ao gênero. Neste caso não é exceção, e o discurso de igualdade nas FARC apresentou aspectos ambíguos, que simultaneamente podem permitir certas liberdades às mulheres, mas também cerceiam seus direitos.

Lá, homem e mulher, dizem que não se discrimina; você, se é homem, faz qualquer coisa, e a mulher também, não há diferenças; a única diferença é em relação ao sexo, mas o resto é normal; você tem às vezes que dormir com um homem, já a mulher decidirá se vai fazer algo com ele, a gente tem que aprender a tratar-se assim com os homens, como se fôssemos dois homens ou duas mulheres (Carol, excombatente das FARC apud NINO VEGA, 2016, p.35)

O âmbito de relações afetivas, sexuais e reprodutivas era regulado pela hierarquia das FARC. Desde que com consentimento do Secretariado e com a restrição do número de parceiros (STANSKI, 2006; TURNER, 2016), as mulheres poderiam ter os companheiros que desejassem; o que implicava em um ambiente de certa liberdade sexual. Entretanto, os membros deviam colocar as obrigações como guerrilheiros combatentes em primeiro plano, de modo que 
se fosse preciso, casais eram separados em nome do conflito e de seus afazeres (FERRO; URIBE, 2002 apud SAYAGO, 2016).

Embora a maior parte dos relatos identificados nos relatórios do Human Rights Watch (2003) aponte para tolerância zero para com estupros e assédio sexual, muitos descreveram o uso de autoridade dos comandantes para arranjar relações sexuais com jovens guerrilheiras em troca de privilégios e proteção (HRW, 2003; STANSKI, 2006). Os relacionamentos não chegavam a ser forçados, mas se desenvolviam em contextos de grande diferencial de poder que deixavam pouca escolha para as mulheres e meninas ${ }^{6}$. Os comandantes tinham autoridade para decidir sobre os cargos, o uso dos recursos e, principalmente, sobre a vida e a morte dos guerrilheiros (HRW, 2003).

\begin{abstract}
Quando as meninas se juntam às FARC, os comandantes escolhem entre elas. Há pressão. As mulheres têm a palavra final, mas querem estar com um comandante para serem protegidas. Os comandantes as compram. Eles dão dinheiro e presentes a uma garota. Quando você está com um comandante, você não precisa fazer o trabalho duro. Então, a maioria das meninas mais bonitas estão com os comandantes(Carolina, entrevista para Human Rights Watch feita em Bucaramanga, 2002 apud HRW, 2003, p.57; tradução livre).
\end{abstract}

Além disso, os homens tinham liberdade para ter como parceiras mulheres que não fossem necessariamente combatentes, enquanto as guerrilheiras só podiam ter relacionamentos com membros do grupo (SAYAGO, 2016). Desse modo, mulheres eram instrumentalizadas para atrair e manter a presença e lealdade de homens no movimento (TURNER, 2016; WELSH, 2015).

O controle sexual e reprodutivo que foi desenvolvido dentro das FARC pode ser compreendido à luz do pressuposto de que os corpos femininos são "naturalmente" inferiores, sendo a sexualidade feminina vista como ameaça ao objetivo coletivo do grupo (COSTA, 2008). Quando inseridas no grupo, as

\footnotetext{
6 “Você vê muitos comandantes com garotas realmente jovens. O Comandante Topo tinha cinquenta e dois anos. Ele tinha uma namorada de dezesseis anos. Isso é típico. Eles cuidam das garotas jovens e bonitas." (Ángela, entrevista para a Human Rights Watch feita em Bogotá, 2002 apud HRW, 2003, p.57; tradução livre)
} 
mulheres eram obrigadas a usarem métodos contraceptivos (camisinha, pílula ou outros dispositivos corporais) e abortos podiam ser feitos sem a anuência das grávidas, interferindo tanto em sua liberdade de decisão e controle sobre seu corpo, quanto a sua saúde sexual e reprodutiva (SAYAGO, 2016; STANSKI, 2006).

O pior é que você não pode ter um bebê. Dois anos atrás, em 2000, fiquei grávida. Eles me deram um aborto, mas eles não me disseram antecipadamente que iriam fazê-lo. Eles me disseram que estavam verificando. Eu queria ter o bebê. (Ángela entrevista para Human Rights Watch feita em Bogotá, 2002 apud HRW, 2003, p.59; tradução livre).

Salienta-se que não havia o devido acompanhamento ginecológico, de modo que podiam ocorrer complicações para a saúde das mulheres, sobretudo as mais jovens, que não tinham entendimento pleno da funcionalidade dos dispositivos colocados em seus corpos, apenas sabiam que eram condições de permanência no grupo. Em alguns casos, quando os filhos nasciam ${ }^{7}$, muitos não eram criados pela mãe para não comprometer a lealdade das mulheres à causa (WELSH, 2015). Aquelas que não abriam mão de seus filhos, por sua vez, precisavam esconder a gravidez e fugir da guerrilha para dar à luz com segurança (SAYAGO, 2016), a menos que fossem parceiras dos comandantes, conforme relato de guerrilheira:

A primeira coisa que lhe dizem quando chega lá é que é melhor você
cuidar de si mesma para que não fique grávida. Eles fazem você
receber injeções e você tem que fazer isso. Eles podem enviá-la para
um conselho de guerra e matá-la se engravidar. Na maioria das vezes,
eles fazem você ter um aborto. Alguns querem, mas outros não.
Somente namoradas de comandantes podem ter seus bebês. Elas
usam uma coroa. Conheço dois casos de mulheres que engravidaram.
Uma ganhou o conselho de guerra porque os companheiros gostavam
dela, então eles votaram contra matá-la e ela estava escondendo sua
gravidez, então ela já estava com cinco ou seis meses de gravidez.
Caso contrário, eles a matariam por estar grávida e por esconder a
gravidez. Você não pode fazer isso por lá. A outra era a namorada de
um comandante, então ela não precisava ter um aborto, mas o que
aconteceu foi que ela descobriu que seu namorado, o comandante,

\footnotetext{
${ }^{7}$ Apenas $8 \%$ das mulheres terminam o processo de gravidez (SAYAGO, 2016).
} 
estava dormindo com outra pessoa, então ela se livrou do bebê. $\mathrm{Na}$ maioria das vezes mulheres grávidas precisam abortar. Isso ou elas morrem. ("Flor", guerrilheira das FARC em testemunho a MENDEZ, 2012, p.152-153; tradução livre).

É importante não apenas vitimizar as guerrilheiras reconhecendo que muitas promotoras do discurso e ideologia do movimento acreditavam que abdicar de filhos e do controle de seus corpos era parte de seu compromisso com o grupo. Entretanto, salienta-se que tal postura reafirmava 0 ideal da masculinidade militar como superior aos valores associados ao feminino, como a reprodução. Esta reafirmação do ideal militar legitima os conflitos e a cultura de violência enquanto gera entraves para a efetiva construção da paz. Assim, levanta-se, no próximo tópico, a relevância da atuação de mulheres nas negociações de paz na Colômbia.

\section{V- $\quad$ A PARTICIPAÇÃO FEMININA NA NEGOCIAÇÃO DA PAZ}

Quatro importantes processos de negociação oficias entre governo e as FARC podem ser identificados, sendo iniciados, respectivamente, pelos governos de Belisário Betancur Cuartas (1982-1986), César Gaviria Trujillo (1990-1994), Andrés Pastrana Arango (1998-2002) e Juan Manuel Santos (2010-) (SILVA; DANTAS, 2016).

A primeira experiência de estabelecimento de diálogo ocorreu no governo do ex-presidente Belisario Betancur. A oposição das Forças Armadas às negociações, que previam ampla anistia para membros de grupos armados ilegais, levou à estruturação de grupos paramilitares (BEJARANO, 2001 apud SILVA; DANTAS, 2016). Além do fenômeno paramilitar e das guerrilhas, o aumento do narcotráfico, financeiramente associado a estes grupos, aumentou a complexidade do cenário (HENAO, 2012 apud SILVA; DANTAS, 2016).

O regime de César Gaviria (1990-1994), por sua vez, apesar de dialogar com as FARC, não logrou estabelecer um cessar-fogo, e as negociações foram 
interrompidas pelo sequestro e posterior assassinato do político conservador Argelino Durán Quintero (DARIO, 2014). A partir de 1998, Andrés Pastrana assumiu o poder e iniciou um processo de paz optando pelo estabelecimento de uma zona desmilitarizada na região de El Caguán, onde ocorreriam os diálogos (CENTRO NACIONAL DE MEMÓRIA HISTÓRICA, 2014 apud SILVA; DANTAS, 2016). Estas negociações também fracassaram, mas durante esse período, a presença da comunidade internacional nos processos de paz do país aumentou como o "Grupo de Amigos do Processo de Paz com as FARC-EP", composto por Canadá, Cuba, Espanha, França, Itália, México, Noruega, Suécia, Suíça e Venezuela, além de organizações multilaterais, organizações não governamentais (ONGs) e setores da sociedade civil colombiana e estrangeira (VELÁSQUEZ, 2003 apud SILVA; DANTAS, 2016).

Durante o regime de Uribe, apesar de haver um endurecimento no tratamento das FARC, enquadradas como terroristas, promoveu-se a negociação com os grupos paramilitares, visando sua desmobilização e reintegração à sociedade a partir do marco jurídico da Lei da Justiça e Paz de 2005 (DARIO, 2014). Essa lei se tornou um precedente importante para a reabertura do diálogo com a guerrilha, e a partir dela, em 2012, o presidente Juan Manuel Santos confirmou publicamente que estava em contato com as FARC com o objetivo de alcançar uma fórmula que pudesse levar ao fim do conflito.

O contexto era de debilidade militar no grupo guerrilheiro, que sofreu baixas em seu contingente, perdeu legitimidade política, viu seus principais líderes serem assassinados e sua capacidade de mobilidade e comunicação seriamente comprometida (DARIO, 2014). As conversas desenvolveram-se em Havana com a facilitação de Cuba e Noruega, que buscaram estabelecer soluções duradouras, lidando com as causas estruturais do conflito, além de levar em conta o narcotráfico, as vítimas do conflito, o estabelecimento de uma jurisdição especial para a paz e, de forma extraordinária, abarcando a temática de gênero (SILVA; DANTAS 2016). 
Tradicionalmente, acordos de paz abordam os problemasrelacionados às relações entre nação e Estado, a viabilidade de um Estado multiétnico e os requisitos da democracia moderna (CHINKIN, 2003), mas excluem um aspecto significativo da sociedade moderna que tem implicações tanto para a determinação de prioridades e agendas, como para a participação no processo de paz: o papel das mulheres na sociedade e as relações de gênero.

Dessa forma, o acordo firmado entre as FARC-EP e o governo colombiano mostrou-se inovador ao incluir as perspectivas das mulheres, que raramente eram incluídas nas negociações quando os grupos armados abaixam suas armas. ${ }^{8}$ Sendo cerca de $30 \%$ a $40 \%$ dos membros da guerrilha mulheres, desconsiderá-las seria um erro crucial. Salienta-se, assim, a importância da inclusão das perspectivas das mulheres combatentes e daquelas das comunidades onde os ex-combatentes se reassentariam à medida em que as negociações se desenrolassem (O'NEILL, 2015).

Quando a mesa da paz foi lançada na Noruega, os homens ocuparam todos os assentos, com exceção daquele detido pela moderadora norueguesa. Foi ao longo das negociações de paz que as mulheres aproveitaram todas as oportunidades e mecanismos disponíveis para participar do processo, fazendose presentes em conferências da sociedade civil, grupos de trabalho e iniciativas de pesquisa sobre os itens da agenda nas tabelas de paz de Havana. Em 2012 e 2013, por exemplo, elas participaram dos fóruns da sociedade civil estabelecidos a pedido dos partidos em Havana e facilitados pelo Sistema das Nações Unidas na Colômbia e pelo Centro de Reflexão e Acompanhamento das Conversações de Paz da Universidade Nacional, em que se discutiu sobre política de desenvolvimento agrário, participação política, culturas ilícitas e tráfico de drogas e vítimas (BOUVIER, 2016).

Após o primeiro ano de negociações de paz, o compromisso persistente das mulheres colombianas e seus aliados internacionais abriu o processo de

\footnotetext{
8 Uma análise das Nações Unidas de 31 processos de paz entre 1992 e 2011 mostra que as mulheres representam apenas $4 \%$ dos signatários, $2,4 \%$ dos principais mediadores, $3,7 \%$ das testemunhas e $9 \%$ dos negociadores (CAMPOY, 2016).
} 
construção da paz às mulheres e vítimas de diversas populações em todo o país. A mudança ocorreu após a Cúpula Nacional das Mulheres pela Paz em outubro de 2013, iniciada pela associação de nove organizações de mulheres colombianas de diferentes origens étnicas, regionais, culturais e políticas ${ }^{9}$.

Contando com o apoio da ONU - Mulheres e do sistema das Nações Unidas na Colômbia, bem como embaixadas e parceiros de desenvolvimento importantes presentes no país, nesse evento as mulheres apresentaram três demandas principais: que as partes permanecessem na mesa até que um acordo fosse alcançado; que as mulheres fossem incluídas na mesa da paz e em todas as fases do processo; e que as necessidades, interesses e experiências de conflito das mulheres fossem consideradas durante as negociações. Essa Cúpula foi crucial para garantir a abertura das mulheres como plenipotenciárias à delegação de paz do governo, culminando na nomeação de Nigéria Rentería e María Paulina Riveros como negociadoras plenipotenciárias (BOUVIER, 2016).

Alguns meses depois, foi criada uma subcomissão de gênero encarregada de revisar o acordo para assegurar que as demandas das mulheres fossem representadas, considerando também os direitos LGBTI (CAMPOY, 2016). Como elencado María Paulina Riveros, co-presidente da subcomissão de Gênero:

\begin{abstract}
Um acordo de paz que adota uma abordagem de gênero é aquele em que todos os homens e mulheres, heterossexuais e homossexuais, bissexuais e pessoas com diversas identidades são concebidas como cidadãos, como sujeitos políticos como atores e interlocutores visíveis de diálogo social, como eixo de modelos de desenvolvimento iguais (EQUIPO PAZ GOBIERNO, 2016, tradução livre).
\end{abstract}

\footnotetext{
${ }^{9}$ A associação era formada pela Casa de la Mujer, Ruta Pacífica de las Mujeres, Red Nacional de Mujeres, Mujeres por la Paz, Colectivo de Pensamiento Acción Mujeres, Paz y Seguridad, Grupo de Seguimiento de la Resolución 1325, Conferencia Nacional de Organizaciones Afrocolombianas (CNOA), Iniciativa de Mujeres Colombianas por la Paz (IMP), e Asociación Nacional de Mujeres Campesinas, Negras e Indígenas de Colombia (ANMUCIC) (National Summit of Women for Peace, 2013 apud BOUVIER, 2016).
} 
Uma equipe de oito mulheres capacitadas do Alto Comissariado para os Escritório de Paz liderou o processo do lado do governo. Ressalta-se a atuação de Mónica Cifuentes, Elena Ambrosi e Marcela Durán, que gerenciaram as estratégias jurídicas, temáticas e de comunicação para a equipe. Além disso, $80 \%$ do pessoal do Gabinete do Alto Comissário para a Paz, gabinete presidencial de apoio ao processo de paz, são mulheres (BOUVIER, 2016).

As guerrilheiras das FARC também conseguiram participação e visibilidade em sua delegação de paz. ${ }^{10} \mathrm{Em}$ abril de 2013, a comandante Victoria Sandino se juntou à equipe de negociação, embora não como uma plenipotenciária e, em fevereiro de 2015, a delegação das FARC em Havana foi composta por mais de $40 \%$ de mulheres, incluindo várias comandantes, refletindo a composição de gênero das FARC como um todo (BOUVIER, 2016).

As mulheres também compuseram $60 \%$ da delegação de vítimas que viajaram para Cuba para dar recomendações. As sobreviventes apresentaram fortemente a questão da violência sexual em conflitos armados, resultando na inclusão da violência sexual como crime contra a humanidade pelo Acordo sobre as Vítimas do Conflito publicado em Dezembro de 2015, sem possibilidade de anistia (NOBEL WOMEN'S INITIATIVE, 2016).

Oito áreas temáticas que incluíam a questão de gênero nos acordos de paz da Colômbia com as FARC foram anunciadas por María Paulina Riveros. Eram elas: acesso à propriedade rural para mulheres; garantias dos direitos econômicos, sociais e culturais das mulheres e "pessoas com diversas orientações e identidades sexuais"; promoção da participação das mulheres na representação, na tomada de decisões e na resolução de conflitos; prevenção de riscos específicos às mulheres; acesso à verdade e à justiça e medidas contra a impunidade; reconhecimento público, divulgação e combate à estigmatização do trabalho político das mulheres; ação institucional para fortalecer as

\footnotetext{
${ }^{10}$ As mulheres estiveram ativas nos programas de comunicação das FARC. Em outubro de 2013, as guerrilheiras lançaram sua própria página na Internet que hospeda uma variedade de apresentações multimídia, narrativas e entrevistas sobre as perspectivas e vidas das mulheres das FARC (BOUVIER, 2016).
} 
organizações de mulheres; e, finalmente, desagregação de dados por sexo (KRYSTALLI, 2016).

Além disso, foi possível notar o impacto da participação das mulheres no processo de paz simplesmente pela redação do acordo. Cada vez que há menção da palavra "homens", ela vem seguida por "e mulheres", denotando a cautela em incluir o gênero feminino. A palavra "mulheres" por si só aparece dezenas de outras vezes em seções inteiras dedicadas a políticas destinadas a colocá-los em pé de igualdade, incluindo o acesso especial ao financiamento para trabalhar na sua própria terra, creches rurais, programas educativos para promover a sua participação política e uma ênfase especial em julgar aqueles que prejudicaram as mulheres (CAMPOY, 2016).

As mulheres desempenharam um papel fundamental nas negociações de paz colombianas, obtendo reconhecimento internacional como algo inovador que deve ser levado a outros processos de paz (WOMEN FOR WOMEN INTERNATIONAL, 2017). Ocuparam grandes comissões, subcomissões e grupos de trabalho, e embora esses papéis geralmente não sejam contados quando se olha para os papéis das mulheres nos processos de paz, são postos influentes que proporcionaram oportunidades para que elas se envolvessem e contribuíssem significativamente e de forma qualificada em diversos níveis, inclusive nos mais altos escalões da liderança pacificadora (BOUVIER, 2016).

Salienta-se, no entanto, que não houve fácil aceitação de tais mobilizações em prol da inclusão de mulheres e da promoção da igualdade de gênero. Os temas que envolviam essa questão foram fortemente combatidos pelos setores conservadores do país, os quais argumentavam que o acordo punha "em perigo a família tradicional". Grupos cristãos colombianos que desaprovam as políticas do governo Santos no que se refere aos direitos sociais como o casamento entre homossexuais, a adoção por casais do mesmo sexo, a lei do aborto e iniciativas educacionais inclusivas vêm denunciando os acordos de paz como estabelecedores de privilégios para a comunidade LGBTI. Em protesto, a população evangélica saiu às ruas em várias cidades do país contra a "doutrinação hegemônica da identidade de gênero" (MARCOS, 2016). 
Essa mobilização foi instrumentalizada por políticos que se posicionavam contra o acordo, que demonizaram sua "abordagem de gênero" (RAMIREZ, 2016). Tal postura pode ser exemplificada pela atuação do ex-presidente Álvaro Uribe, o maior porta-estandarte do não ao acordo, que justificou sua posição em nome da defesa da família tradicional (LAFUENTE, 2016).

Salienta-se que, para além dos efeitos mais imediatos de inclusão das mulheres nos processos de negociação da paz e nas provisões do acordo, a inclusão de mulheres e de questões de gênero eram centrais para a efetiva construção da paz na Colômbia. Indo além da visão limitada de que a paz se resume à ausência de conflitos e guerras proposta pelos estudos de paz ${ }^{11}$ (GALTUNG, 1969), e aceitando que para a efetiva construção da paz é necessário lidar com violências estruturais que impedem a construção de uma paz social com a ausência ou redução da violência, é de central relevância considerar a violência estrutural contra as mulheres como um tipo de violência que impacta duramente a sociedade colombiana. Considerar gênero ajuda na construção da paz e no estabelecimento de bases da "justiça de transição" (KRYSTALLI, 2016) e é imprescindível nos acordos de paz da Colômbia, pois o país não se encontra em um contexto pacífico devido, em grande medida, à desigualdade de gênero. A condição de desigualdade de gênero no país é um fator convergente para a ausência de paz e para a impossibilidade de redução da violência, de forma que, para ser eficaz, o processo de construção de paz pede maior igualdade de gênero na Colômbia.

Fica claro, a partir da análise dos motivos que embasam a inserção feminina nas FARC, a situação de vulnerabilidade das mulheres na sociedade

\footnotetext{
${ }^{11}$ Galtung divide a paz em duas terminologias: paz negativa e paz positiva (GALTUNG, 1969; 1996). A paz negativa é simplesmente a ausência de violência direta, como o advento de guerras ou do homicídio intencional. Já a paz positiva é uma condição de certo modo utópica, na qual há uma ausência de conflito tanto direto como indireto. A redução da violência estrutural rumo à paz positiva significaria uma sociedade em que prevalece um ambiente adequado para um processo de busca autônoma por qualidade de vida, crescimento pessoal, liberdade, igualdade social, equidade econômica e participação (GALTUNG, 1973).
} 
colombiana, e a relevância da promoção da igualdade de gênero sem reafirmar ideais militares para o sucesso da construção da paz na Colômbia.

\section{VI- CONCLUSÕES}

A partir do olhar às questões de gênero que envolvem a inserção e atuação feminina nas FARC, o presente artigo identifica a ambiguidade que marca as expectativas das mulheres ao se inserirem nas FARC e a realidade que as confronta no grupo.

Tratando de questões que impulsionaram mulheres a se envolverem nas FARC, foi abarcado o histórico de violência que marca o país, as difíceis condições de vida e a expectativa de um ambiente mais igualitário onde possam lutar por uma sociedade melhor. O referencial do mito da proteção, calcado em diferenças de gênero entre homens e mulheres, é útil para compreender por que mulheres com poucas opções e em situações de fragilidade podem buscar as FARC, com seu discurso de igualdade entre os marginalizados que se unem contra o capitalismo.

No caso das atividades que as mulheres desempenham dentro do grupo, simultaneamente enquanto se promove o discurso de equidade sob a hierarquia militar do grupo, reafirma-se o sexismo na presunção de que os corpos femininos são mais fracos e precisam se adaptar a um ideal de soldado forte, belicista e de pensamento estratégico e racional. Aquelas que se adequam a este ideal conseguem ascender na hierarquia e as que não o fazem atuam em áreas de apoio, tradicionalmente ocupadas por mulheres e menos valorizadas, ainda que estratégicas. Exemplo disso são a espionagem e a inteligência, que instrumentalizam a presença feminina valendo-se de concepções sexistas tradicionais em prol dos objetivos do grupo.

No âmbito da questão sexual e reprodutiva, ficam mais claras as ambiguidades que marcam as relações entre homens e mulheres nas FARC. Embora haja, no grupo, elementos que sejam normalmente relacionados à 
liberdade sexual feminina, como o uso de métodos anticoncepcionais, a falta de liberdade para escolher se utilizam ou não estes métodos, ou se podem ou não ter seus filhos, mostra que os corpos das mulheres são dominados, e que a possibilidade de maternidade, característica deles, é vista como uma fraqueza, que coloca em risco o objetivo militar do grupo. Ademais, fica claro como os corpos femininos também são objetificados, podendo seu acesso ser obtido pelos líderes da hierarquia ou violentamente atacados dentro das dinâmicas do conflito.

A partir do relato da importância das mulheres no estabelecimento de um acordo de conciliação entre o grupo e o governo, além da efetiva tentativa de construção da paz no país, pode-se concluir que mulheres têm, de fato, grande importância no grupo e no conflito. Ainda, a onda conservadora que emergiu contra o acordo de paz mostra a persistente necessidade de desenvolvimento da consciência de gênero ainda a ser perseguida no país.

O artigo demonstra que os papéis das mulheres nas FARC são múltiplos e merecem exame atento, salientando a importância do uso da categoria de gênero e de perspectivas feministas em estudos na área de segurança, a qual, tradicionalmente associa as mulheres em situações de conflitos a belas almas que necessitam de proteção. Para além de vítimas e atores dóceis, como tradicionalmente são retratadas, as mulheres podem tanto manter-se dentro da simbologia das belas almas em posições auxiliares aos homens, quanto se aproximarem do ideal dos guerreiros justos adequando-se ao modelo de masculinidade que ele representa e reafirmando lógicas masculinistas. Reafirma-se, a guisa de consideração final, como a atuação feminina nas negociações de paz aponta para a possibilidade de um caminho alternativo ao histórico de conflitos que marca a sociedade colombiana, que não é questionado quando é dada continuidade à cultura de violência embasada e modelos militares masculinistas.

\section{Referências Bibliográficas}


BOUVIER, Virginia M. Gender and the Role of Women in Colombia's Peace Process. Nova York: UN Women. 2016. Disponível em: $<$ http://www.unwomen.org/-

/media/headquarters/attachments/sections/library/publications/2017/womencolombia-peace-process-en.pdf?vs=17>. Acessado em 16 de abril de 2017.

BRETTSCHNEIDER, Marla. Review - Bombshell: The Many Faces of Women Terrorists.Londres: E- International Relations. 2014. Disponível em: $<$ http://www.e-ir.info/2014/01/10/review-bombshell-the-many-faces-of-womenterrorists/>. Acessado em 16 de abril de 2017.

CAMPOY, Ana. No Women, No Peace: Colombian women made sure gender equality was at the center of a groundbreaking peace deal with the FARC. Quartz. 2016. Disponível em: <https://qz.com/768092/colombian-women-made-suregender-equality-was-at-the-center-of-a-groundbreaking-peace-deal-with-thefarc/>. Acessado em 17 de abril de 2017.

CEPAL. Observatório da Igualdade de Gênero. S.d. Disponível em:<http://oig.cepal.org/pt/indicadores/tempo-trabalho-nao-remuneradosegundo-rendimentos-proprios-sexo>. Acessado em 20 de abril de 2017.

CERAC. Violencia juvenil em contextos urbanos/Centro de Recursos para El Análisis de Conflictos. Bogotá: Opciones Gráficas Editores, 2014. Disponível em: $<$ http://www.cerac.org.co/es/publicaciones/libros/violencia-juvenil-en-contextosurbanos/>. Acessado em 8 de Julho de 2017.

CHINKIN, Christine. Peace Agreements as a Means for Promoting Gender Equality and Ensuring Participation of Women. United Nations: Division for the Advancement of Women (DAW), 2003.

COSTA, Grazielle Furtado Alves da. Entre "guerreiros justos" e "almas belas" proteção, poder e resistência política nos discursos e nas práticas das mulheres colombianas organizadas pela paz". Tese (Doutorado em Relações Internacionais) - Pontifícia Universidade Católica do Rio de Janeiro, Rio de Janeiro, 2008. Disponível em: $<$ http://pct.capes.gov.br/teses/2008/31005012026P2/TES.pdf>. Acessado em 10 de julho de 2017.

COUNCIL ON HEMISPHERIC AFFAIRS. FARC - Rebels with a Cause?2010. Disponível em: <http://www.coha.org/farc-\%E2\%80\%93-rebels-with-a-cause/>. Acessado em 15 de abril de 2017.

DARIO, Diogo Monteiro. Os diálogos de paz entre as FARC e o governo Santos na Colômbia.Policy Brief Global South Unit for Mediation, 2014.Disponível em: $<$ http://www.iri.puc-

rio.br/uploads/content/files/fee9fcdb4511c52338c37e8406950a94a5cb70fe.pdf> . Acessado em 25 de agosto de 2017.

ELSHTAIN, Jean Bethke. Women and War. Chicago: University Press, 1987. 
ENLOE, Cynthia. Bananas, Beaches and Bases: Making Feminist Sense of International Politics. 2nd ed.Berkeley e Los Angeles: University of California Press, 2014.

EQUIPO PAZ GOBIERNO. María Paulina Riveros habla sobre la inclusión del enfoque de género en los acuerdos de paz. 2016. Disponível em: $<$ http://equipopazgobierno.presidencia.gov.co/prensa/declaraciones/Paginas/m aria-paulina-riveros-inclusion-enfoque-genero-acuerdos-paz-colombia-.aspx> . Acessado em 17 de abril de 2017.

ESTADÃO. Colômbia denuncia que Farc recrutaram 11.556 crianças entre 1975 e 2014.2016. Disponível em: $<$ http://internacional.estadao.com.br/noticias/geral,colombia-denuncia-que-farcrecrutaram-11556-criancas-entre-1975-e-2014,1869763>. Acessado em 20 de abril de 2017.

FOLHA DE SÃO PAULO. Após acordo de paz na Colômbia, Farc iniciam entrega de crianças-soldados. 2016. Disponível em: $<$ http://www1.folha.uol.com.br/mundo/2016/09/1811997-apos-acordo-de-pazna-colombia-farc-iniciam-entrega-de-criancas-soldados.shtml>. Acessado em 20 de abril de 2017.

GALTUNG, Johan. World Indicators Program.Bulletin of Peace Proposals, v.4, n.4, p.354-358, 1973.

. Peace by Peaceful Means: Peace and Conflict, Development and Civilization. London: Sage, 1996.

. Violence, Peace and Peace Research. Journal of Peace Research, v.6, n.3, p.167-191, 1969.

GJELSVIK, Ingvild Magnæs. Women, war and empowerment: A case study of female ex-combatants in Colombia. 2010. Dissertação de Mestrado no Curso de Paz e Transformação de Conflitos, University Of Tromsø, 2010.

GUEVARA, Kalki Zumbo Coronel. As Forças Armadas Revolucionárias da Colômbia (FARC) e sua atuação no cenário internacional. Revista eletrônica de Direito Internacional, v. 6, 2010. Human Rights Watch. "You'll Learn Not to Cry": Child Combatants in Colombia. 2003. Disponível em: <https://www.hrw.org/reports/2003/colombia0903/colombia0903.pdf>. Acessado em 10 de julho de 2017.

KRYSTALLI, Roxanne. The Colombian peace agreement has a big emphasis on the lives of women. Here's how.2016. Disponivel em: $<$ https://www.washingtonpost.com/news/monkey-cage/wp/2016/08/19/thecolombian-peace-agreement-gives-gender-issues-a-central-role-heres-why-thisis-so-important/?utm term=.2356634c44f9>. Acessado em 17 de abril de 2017.

LAFUENTE, Javier. Colômbia diz 'não' ao acordo de paz com as FARC. 2016. Disponível em: 
$<$ http://brasil.elpais.com/brasil/2016/10/02/internacional/1475420001 242063.ht ml> Acessado em 21 de abril de 2017.

MARCOS, Ana. Voto evangélico é chave na vitória do 'não' no plebiscito da Colômbia.2016. Disponível em: $<$ http://brasil.elpais.com/brasil/2016/10/12/internacional/1476237985 601462.ht ml>. Acessado em 21 de abril de 2017.

MÉNDEZ, Andrea. Militarized Gender Performativity: Women and Demobilization in Colombia's FARC and AUC. 2012. Tese de Doutoradoem Estudos Políticos, Queen's University, 2012.

MONTE, Izadora Xavier do. Gênero e Relações Internacionais: Uma Crítica ao Discurso Tradicional de Segurança. Dissertação de Mestrado em Relações Internacionais, Universidade de Brasília, 2010.

NINO VEGA, Nohora Constanza. A experiência de jovens mulheres como combatentes da guerrilha das FARC e do ELN.Rio de Janeiro: Desidades, v. 11, p. 32-40, jun. 2016. Disponível em: $<$ http://pepsic.bvsalud.org/pdf/desi/v11/n11a04.pdf $>$. Acessado em: 10 de julho de 2017.

Nobel Women's Initiative. Women's role in the Colombian peace process.2016. Disponível em: <https://nobelwomensinitiative.org/womens-role-in-thecolombian-peace-process/>. Acessado em: 17 de abril de 2017.

O DIA. Farc recrutou mais de 11 mil menores entre os anos de 1975 e 2014.2016. Disponível em: <http://odia.ig.com.br/mundoeciencia/2016-05-17/farc-recrutoumais-de-11-mil-menores-entre-os-anos-de-1975-e-2014.html>. Acessado em: 20 de abril de 2017.

O'NEILL, Jacqueline. Are Women the Key to Peace in Colombia?2015. Disponível em: <http://foreignpolicy.com/2015/04/20/are-women-the-key-topeace-in-colombia-farc-talks/>. Acessado em: 14 de abril de 2017.

ONU Brasil. Brasil tem nona maior taxa de homicídio das Américas, diz OMS. 2017.Disponível em: <https://nacoesunidas.org/brasil-tem-nona-maior-taxa-dehomicidio-das-americas-diz-oms/> Acessado em: 8 de Julho de 2017.

ONU Mujeres. Día Internacional de La Mujer 2017.2017.Disponível em: <http://www.unwomen.org/es/news/in-focus/international-womens-day> Acessado em: 8 de Julho de 2017.

Las Mujeres en Colombia. S. d.Disponível em: $<$ http://colombia.unwomen.org/es/onu-mujeres-en-colombia/las-mujeres-encolombia> Acessado em: em 8 de Julho de 2017.

PÉCAUT, Daniel. Breve retrospectiva da formação das FARC. In: PÉCAUT, Daniel. As FARC: uma guerrilha sem fins?. São Paulo: Paz e Terra. 2010, p. 1730. PEREIRA, Letícia. Colômbia: As FARC e os diálogos de paz. Conflitos Internacionais,v. 1, n. 2, p.1-5, 2015.

RAMIREZ, Socorro. ¿Empujando intereses? El Tiempo. 2016. Disponível em: <http://www.eltiempo.com/opinion/columnistas/socorro-ramirez/empujando- 
intereses-socorro-ramirez-columna-el-tiempo-53346> Acessado em: 21 de abril 2017.

SANCHEZ, Junior Alfonso Vargas. As FARC: Métodos e meios de guerra. Rio de Janeiro: Escola Superior de Guerra, 2014.

SANCHEZ, Sergio. Female Fighters and the FARC: 1 Female Fighters and the FARC: Misguided Fight for Emancipation. 2012. Disponível em: $<$ https://www.academia.edu/4462401/Female Fighters and the FARC Misgui ded Fight fo r Emancipation\&gt; >. Acessado em: 13 de abril de 2017.

SAYAGO, María José Uribe. El Estatus de los Derechos Sexuales y Reproductivos de las Mujeres en las FARC. 2016. 31 (Graduação) - Curso de Relações Internacionais, Universidad San Francisco de Quito, Quito, 2016.

SCOTT, Joan W. Gender: A Useful Category of Historical Analysis. The American Historical Review, v. 91, n. 5. dec., pp. 1053-1075, 1986.

SILVA, Barbara Ellynes Zucchi Nobre; DANTAS, Internacionais San Tiago. Os processos de paz entre as FARC-EP e o governo nacional da Colômbia, 2016.

STANSKI, Keith. "Terrorism, Gender, and Ideology: A Case Study of Women Who Join the Revolutionary Armed Forces of Colombia (FARC)". In: FOREST, James. (Ed.). The Making of a Terrorist: Recruitment, Training, and Root Causes. Praeger Security International. 2006, p. 136-150.

TICKNER, J. A. "Feminist Perspectives on International Relations". In: CARLSNAES, W.; RISSE-KAPPEN, T.; SIMMONS, BA. (Eds.) Handbook of International Relations. London: Sage Publications Inc, 2002, p.95-118.

TURNER, Kathleen. Femme Fatales: Why Women are Drawn to Fight With Violent Extremist Groups.2016. Disponível em: $<$ https://s3.amazonaws.com/fwvcorp/wpcontent/uploads/20160419155228/FemmeFatales.pdf>. Acessado em: 14 de abril de 2017.

UNICAMP. Exclusão social. Informe Padronizado. Brasil: MISEAL. 2013.

VEGA, Nohora Constanza Niño. A experiência de jovens mulheres como combatentes da guerrilha das FARC e do ELN. Desidades, n. 11, jun., p.32-39, 2016.

WELSH, Alexandra Mary. Women of the Jungle: Guerrilleras on the front lines of the FARC-EP. Glendon Journal Of International Studies, v. 8, n. 1-2, p.1-14, 2015.

WOMEN FOR WOMEN INTERNATIONAL. The role of women in the Colombian peace negotiations, 2017.2 Disponível em: <http://www.womenforwomen.org/node/987>. Acessado em: 17 de abril de 2017.

ZWEHL, Philipp. Violence against women in Colombia fueled by machismo culture and 'institutional weakness'. 2014. Disponível em: 
$<$ http://colombiareports.com/violence-women-colombia-fueled-machismoculture-institutional-weakness/>. Acessado em: 20 abril de 2017.

Recebido em 24 de abril de 2017. Aprovado em 20 de julho de 2017. 